\title{
A Longitudinal Study Of Finances At A State Supported University
}

Gilbert J. McKee, (Email: gjmckee@csupomona.edu), California State Polytechnic University

\begin{abstract}
This study examines information on expenditures at the university and state system levels and identifies trends in the expenditures that support the educational mission of the university. The study period is from fiscal year 95-96 to fiscal year 01-02. This seven-year period encompasses the recovery of state support after the budget reductions of the early 90's to the beginning of a new round of budgetary constraints. The system-wide data is used to compare trends in the state university expenditures and peer campus expenditures with trends in this university's financing. The annual campus expenditures are analyzed by division and college or school to identify trends and for comparisons. Significant disparities in the allocation of resources at the state and campus levels are evidenced.
\end{abstract}

\section{INTRODUCTION}

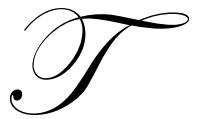

his longitudinal study is a continuation of an earlier analysis that was the basis for an article: "Finances at a State Supported University: A Case Study" that was published in the Journal of Interdisciplinary Studies, Fall, 1998. The University had changed after the 1995-96 Fiscal Year to a new format for the University Expenditure Report to provide the Chancellor's Office with uniform financial data. These campus reports are consolidated into the California State University Combined Statement of Revenues and Expenditures. At the time of the previous study, the University had only the annual expenditure reports for 1995/1996 and 1996/97 in the University Library's Special Collections. The Campus Academic Senate and University President had resolved a dispute over faculty representation on the University Budget Committee and the extent of faculty input in the budget process at the time the earlier paper was written. A reconstituted University Budget Advisory Committee (UBAC), a new Academic Affairs Budget Advisory Committee (ABAC) and College Budget Committees were instituted. This paper will examine the extent to which that increased faculty input has affected the allocation of resources over the seven year period. The cyclical nature of funding and enrollments creates difficulties for budget management. The Table I illustrates the recent cycle. Enrollment in 2001-2002 has reached the level of 1990-1991. The mantra of the California State University System throughout this period has been Access, Quality and Affordability. However, political and policy decisions have placed Access and Affordability ahead of Quality.

Table I

Expenditures and Enrollment through the Cycle ${ }^{1-7,9}$

\begin{tabular}{|c|c|c|}
\hline Year & $\begin{array}{c}\text { Total General Fund Cost including } \\
\text { appropriated receipts (\$millions) }\end{array}$ & Full Time Equivalent Students (FTE) \\
\hline $90-91$ & 113.599 & 16,579 \\
\hline $91-92$ & 115.142 & 16,079 \\
\hline $92-93$ & 112.500 & 15,018 \\
\hline $93-94$ & 111.358 & 14,096 \\
\hline $94-95$ & 113.883 & 13,799 \\
\hline $95-96$ & 120.677 & 14,169 \\
\hline $96-97$ & 129.249 & 14,318 \\
\hline $97-98$ & 133.623 & 14,819 \\
\hline $98-99$ & 143.972 & 15,375 \\
\hline $99-00$ & 149.839 & 15,649 \\
\hline $00-01$ & 163.071 & 16,226 \\
\hline $01-02$ & 169.367 & 17,015 \\
\hline
\end{tabular}




\section{SOURCES AND USES OF FUNDS-DIVISIONAL ANALYSIS FOR THE CAMPUS}

The University Expenditure Reports contain information detailing the sources and uses of funds for the respective fiscal years. The glossary of the document contains definitions. Key definitions include:

- $\quad$ Fiscal Year: The period from July 1 to June 30 of the following year.

- Divisions: On this campus the colleges/schools/units are part of six divisions: President, Academic Affairs, Instructional and Information technology, Administrative Affairs, Student Affairs, and University Advancement.

- $\quad$ General Fund State Support: Funds that the legislature appropriates each fiscal year.

- $\quad$ Reimbursements: Includes faculty release time that is paid out of grants or contracts, leases of campus facilities and other transfers or expenditures related to the university's mission.

The global view of the sources of funds follows:

Table II

Sources of Funds (\$millions) ${ }^{1-7}$

\begin{tabular}{|l|c|c|c|c|c|c|c|}
\hline & F.Y. 01-02 & F.Y. 00-01 & F.Y.99-00 & F.Y.98-99 & F.Y.97-98 & F.Y.96-97 & F.Y.95-96 \\
\hline Gen. Fund & 165.663 & 162.521 & 148.763 & 140.642 & 131.706 & 125.892 & 120.034 \\
\hline Reimburse & 1.371 & 1.688 & 2.188 & .206 & 2.684 & 1.626 & 2.137 \\
\hline Cont. Ed. & 2.094 & 2.623 & 2.887 & 2.590 & 1.847 & 1.946 & 1.984 \\
\hline Housing & 4.113 & 3.932 & 3.570 & 3.308 & 3.663 & 2.996 & 3.974 \\
\hline Lottery & 2.472 & 2.540 & 1.699 & 1.253 & 1.842 & 1.874 & 2.323 \\
\hline Parking & 1.612 & 1.735 & 1.566 & 1.501 & .971 & .969 & 1.175 \\
\hline Total & 177.325 & 175.040 & 160.673 & 149.500 & 142.715 & 135.303 & 131.629 \\
\hline G.F./ Tot. & $93.42 \%$ & $92.85 \%$ & $92.59 \%$ & $94.07 \%$ & $92.29 \%$ & $93.04 \%$ & $91.19 \%$ \\
\hline
\end{tabular}

After the State budget deficits of the early 90's and subsequent reduction of general fund support and a dramatic reduction in student enrollment, the President asserted that the University would change from a state supported institution to a state assisted institution. The University would reduce its reliance on general fund dollars to below $80 \%$. The intent was to moderate the effects of cyclical general fund dollar financing. Table II shows that the dependence of the University on general fund support has actually increased over the period. General fund dollars grew at a $5.52 \%$ rate as contrasted with a $5.09 \%$ growth of dollars from all sources. This leadership failure will exacerbate the effects of the anticipated multiple year reductions of general fund dollars occasioned by the continuing state fiscal crisis and the new governor's budget priorities.

The Uses of Funds in Table III summarizes the expenditures of the six divisions for the respective fiscal year. From the 1996-97 year forward an expenditure entitled university obligations is incurred. This is an euphuism for the additional financial aid that the chancellor committed to provide from general fund appropriations whenever the legislature approves fee increases. This permitted the legislature to avoid appropriating additional funds for financial aid and represents a hidden tax on those students who do not qualify for financial aid. The requested fee increase must be larger than the amount necessary to fund operations. For the 1997-1998 F.Y. University Obligations were 24.1\% of the total Student Fee Income for the Campus.

These changes computed from Table III may be examined as occurring within the following macro environment. Over the seven-year period the General Funds dollars appropriated by the legislature for the California State University increased at annual rate of $8.65 \%$. The Campus General Fund dollars averaged a smaller 5.53\% increase. The FTE taught increased over the period at an annual 3.10\% rate. On this Campus the Vice President for Academic Affairs position has been occupied by eight different individuals. This includes three appointments to the position and five interim appointments ( of one week to a year duration). This lack of leadership may explain why the allocation of funds to instruction failed to keep up with the general fund growth. The Vice President for Student Affairs position has been filled with four different appointments including three interims. Growth of funding has fail- 
Table III

Uses of Funds by Division (\$millions) ${ }^{1-7}$

\begin{tabular}{|l|c|c|c|c|c|c|c|}
\hline & F.Y. 01-02 & F.Y. 00-01 & F.Y.99-00 & F.Y.98-99 & F.Y.97-98 & F.Y.96-97 & F.Y.95-96 \\
\hline Pres. & 1.401 & 1.385 & 1.481 & 1.101 & .786 & .673 & .781 \\
\hline Acad. Aff. & 99.277 & 98.531 & 90.673 & 82.152 & 82.295 & 78.734 & 87.000 \\
\hline IIT & 8.920 & 9.970 & 8.889 & 13.220 & 10.710 & 10.938 & Incl. AA \\
\hline Adm. Aff. & 26.727 & 23.834 & 21.196 & 19.989 & 20.719 & 18.577 & 18.861 \\
\hline Stud. Aff. & 18.520 & 18.451 & 17.034 & 15.931 & 19.504 & 18.619 & 18.861 \\
\hline Univ. Obl. & 7.905 & 7.647 & 7.083 & 6.125 & 6.693 & 5.861 & -------- \\
\hline Univ.Adv. & 2.911 & 2.703 & 2.407 & 2.124 & 2.007 & 1.902 & 1.854 \\
\hline
\end{tabular}

\begin{tabular}{|l|c|}
\hline & Annual Percentage Increase/Decrease \\
\hline President & 10.22 \\
\hline Academic Affairs & $4.75(5$ years $)$ \\
\hline Instructional \& Institutional Technology & -4.00 (5 years) \\
\hline Administrative Affairs & 7.73 \\
\hline Student Affairs & -0.30 \\
\hline University Obligations (Financial Aid) & 6.17 \\
\hline University Advancement & 7.81 \\
\hline
\end{tabular}

ed to keep up with enrollment growth and student services have deteriorated. The President's Office has experienced significant growth. University Advancement has also grown faster than the average general fund growth. The President's performance evaluation that determines his salary increases has a fund raising component. Administrative Affairs oversees the budget preparation and has experienced a comparatively higher growth rate.

\section{Analysis of Costs-College/School Analysis}

Data of the cost per F.T.E. was available for the past five years. Four of those years are in the study period and the costs appear below. The variability of these costs is notable.

Table IV

Cost per FTE by College/School (Dollars) ${ }^{10}$

\begin{tabular}{|l|cr|c|c|c|}
\hline & \multicolumn{7}{|c|}{ F.Y. 01-02 } & FTE & F.Y. 00-01 & F.Y. 99-00 & F.Y. 98-99 \\
\hline Agriculture & 10,245 & 755 & 10,468 & 8,135 & 8022 \\
\hline Business & 5,295 & 2,849 & 5,374 & 5,144 & 5166 \\
\hline CEIS (Education) & 7,068 & 967 & 7,180 & 6,762 & 5602 \\
\hline CLASS (Arts) & 4,028 & 4,897 & 4,026 & 3,901 & 3962 \\
\hline Engineering & 8,274 & 1,572 & 9,378 & 8,616 & 8153 \\
\hline Environ. Design & 6,848 & 961 & 6,504 & 6,705 & 6909 \\
\hline Hospitality Mgmt & 6,784 & 320 & 8,166 & 7,599 & 6868 \\
\hline Science & 5,774 & 3,046 & 5,891 & 5,901 & 5501 \\
\hline
\end{tabular}

\begin{tabular}{|c|c|c|}
\hline & \multicolumn{2}{|c|}{ Annual Percentage Increase/ Decrease } \\
\hline & Cost/FTE & FTE \\
\hline Agriculture & 8.50 & -1.87 \\
\hline Business Administration & 0.83 & 2.46 \\
\hline Education \& Integrative Studies & 8.06 & 5.95 \\
\hline Letters, Arts \& Social Sciences & 0.55 & 3.54 \\
\hline Engineering & 0.49 & 1.73 \\
\hline Environmental Design & -.29 & 3.85 \\
\hline Hospitality Mgmt & -.40 & 8.00 \\
\hline Science & 1.63 & 3.27 \\
\hline University & 1.33 & 3.44 \\
\hline
\end{tabular}


Table IV presents cost/FTE and FTE figures. The lower table computes change over the period. The sitting Governor, Chancellor and then University President have emphasized a commitment to teacher education. That commitment is reflected in the growth of the funds directed to, and enrollment in, the College of Education and Integrative Studies. The Colleges of Arts and Business have lowest cost per FTE. Their relative lower cost has been maintained by significant increases in FTE without the comparable funding increase. These colleges have a student to faculty ratio that exceeds 23:1 in contrast with the University SFR of 19:1. The College of Agriculture and the School of Hospitality Management had FTE for 01-02 of 755 and 320, respectively. A 6\% drop of FTE (that increased cost) in the College of Agriculture and a $20 \%$ increase of FTE (that decreased cost) for the School of Hospitality Management explain these outliers in terms of the observed changes. The College of Environmental Design's Architecture program is "impacted". The College's other programs that do not have enrollment controls and studio instruction whose SFRs are higher experienced the increase of FTE and account for the decline in the College's cost per FTE.

The variability of Cost per FTE is also observed in the Costs of the 23 Campuses that comprise the CSU. The Tables below reflect the campus general fund cost per annual full-time equivalent student.

Table V

Campus General Fund Cost-Small Sized Campus (dollars) ${ }^{9}$

\begin{tabular}{|l|rr|c|c|c|}
\hline Campus & $01-02$ & FTE & $00-01$ & $99-00$ & $98-99$ \\
\hline Bakersfield & 11,275 & 6,090 & 10,506 & 9,663 & 10,659 \\
\hline Humboldt & 12,067 & 7,102 & 11,481 & 11,010 & 10,838 \\
\hline Monterey Bay & 17,799 & 2,839 & 18,840 & 20,469 & 19,717 \\
\hline San Marcos & 13,430 & 5,180 & 11,365 & 11,154 & 12,200 \\
\hline
\end{tabular}

Table VI

Campus General Fund Cost-Medium Sized Campus ${ }^{9}$

\begin{tabular}{|l|cc|c|c|c|}
\hline Campus & $01-02$ & FTE & $00-01$ & $99-00$ & $98-99$ \\
\hline Fresno & 10,193 & 16,518 & 10,190 & 10,093 & 9,665 \\
\hline Pomona & 9,954 & 17,015 & 10,050 & 9,575 & 9,364 \\
\hline San Luis Obispo & 10,017 & 17,060 & 10,312 & 9,834 & 9,873 \\
\hline
\end{tabular}

Table VI

Campus General Fund Cost-Large Sized Campus ${ }^{9}$

\begin{tabular}{|l|cc|c|c|c|}
\hline Campus & $01-02$ & FTE & $00-01$ & $99-00$ & $98-99$ \\
\hline Long Beach & 9,376 & 26,732 & 9,332 & 8,725 & 8,809 \\
\hline Northridge & 9,558 & 23,334 & 9,606 & 9,481 & 9,186 \\
\hline San Diego & 9,776 & 27,701 & 9,780 & 9,289 & 9,231 \\
\hline
\end{tabular}

The College/School cost per FTE and the System-wide Campus cost per FTE reflect the economies of scale. The College of Agriculture cost per FTE is reflective of an agricultural program whose physical facilities span the Campus and may be compared with the Monterey Bay campus cost structure. Monterey Bay is a new campus that occupies an extensive decommissioned military facility and currently has low enrollments. The cost/FTE far exceeds the System average (Table V) of \$9915. The Business, Arts and Science Colleges generate high FTE's and have correspondingly lower costs per FTE comparable to the large sized campuses' cost experiences (Table VI). 
The tables that follow detail major expenses by College or School for F.Y. 95-96 and F.Y. 01-02.

Table VII

F.Y. 95-96 Major Expenditures (\$millions) ${ }^{1}$

\begin{tabular}{|l|c|c|c|c|c|c|c|c|}
\hline & AGR & CLASS & BUS & EGR & ENV & SHM & CEIS & SCI \\
\hline Faculty & 2.740 & 7.775 & 6.717 & 6.531 & 2.530 & .674 & 1.338 & 7.577 \\
\hline $\begin{array}{l}\text { Temporary } \\
\text { Faculty }\end{array}$ & .183 & 2.518 & 1.632 & 1.211 & .540 & .259 & .663 & 1.148 \\
\hline Staff/Admin. & 1.037 & 1.238 & .904 & .996 & .674 & .228 & .445 & 1.402 \\
\hline Benefits & 1.067 & 3.002 & 2.293 & 2.195 & .957 & .309 & .622 & 2.645 \\
\hline Supplies & .175 & .396 & .105 & .163 & .099 & .014 & .101 & .155 \\
\hline $\begin{array}{l}\text { Total } \\
\text { Expenditures }\end{array}$ & 5.470 & 15.492 & 12.499 & 11.364 & 4.920 & 1.541 & 3.427 & 13.318 \\
\hline
\end{tabular}

Table VIII

F.Y. 01-02 Major Expenditures (\$millions) ${ }^{7}$

\begin{tabular}{|l|c|c|c|c|c|c|c|c|}
\hline & AGR & CLASS & BUS & EGR & ENV & SHM & CEIS & SCI \\
\hline Faculty & 3.522 & 9.350 & 8.501 & 7.186 & 2.873 & .808 & 2.249 & 8.749 \\
\hline $\begin{array}{l}\text { Temporary } \\
\text { Faculty }\end{array}$ & .447 & 4.536 & 2.562 & 2.019 & 1.133 & .303 & 1.213 & 3.089 \\
\hline Staff/Admin. & 1.590 & 1.790 & 1.213 & 1.433 & 1.041 & .474 & .927 & 1.982 \\
\hline Benefits & 1.033 & 2.875 & 2.058 & 1.895 & .886 & .297 & .781 & 2.403 \\
\hline Supplies & .403 & .470 & .249 & .302 & .287 & .137 & .358 & .680 \\
\hline $\begin{array}{l}\text { Total } \\
\text { Expenditures }\end{array}$ & 7.735 & 19.721 & 15.083 & 13.003 & 6.582 & 2.170 & 6.835 & 17.588 \\
\hline
\end{tabular}

Table IX

Temporary Faculty as Percent of Total Expenditures for Faculty

\begin{tabular}{|l|c|c|}
\hline Year & $\mathbf{0 1 - 0 2}$ & $\mathbf{9 5 - 9 6}$ \\
\hline Agriculture & 12.0 & 6.3 \\
\hline Letters, Arts \& Social Sciences & 32.7 & 24.5 \\
\hline Business & 23.2 & 19.6 \\
\hline Engineering & 21.9 & 15.64 \\
\hline Environmental Design & 28.3 & 17.59 \\
\hline Hospitality Management & 27.3 & 27.76 \\
\hline Education & 35.0 & 33.13 \\
\hline Science & 26.1 & 13.16 \\
\hline
\end{tabular}

The previous Chancellor negotiated a "Compact" with then Governor Wilson that provided for both funding of current operations and enrollment growth. The growth dollars, however, has been provided at a "marginal cost" that assumes that faculty are hired at the budgetary Assistant III level. The hiring of temporary faculty to service the FTE growth and stay within budget has increased temporary faculty as a percent of total faculty. The University has also failed to recruit new tenure track faculty to replace retired faculty and that has increased the proportion of temporary faculty. The Colleges, over this period, have also been able to reduce the benefit costs by an aggregate \$0.892 million for F.Y. 01-02 as compared with F.Y 95-96. A major explanation of this reduced benefit cost derives from hiring part-time temporary faculty who did not qualify for benefits. The California Faculty Association (CFA) has been successful in securing legislation and in subsequent negotiations to extend benefits to a larger portion of the part-time temporary faculty. CFA also negotiated a provision in the Collective Bargaining Agreement that commits CSU to a number of tenure track searches to address faculty workload issues raised by tenured and tenure track faculty. 
Table X

Staff/Administration as Percent of Total Expenditures (01-02)

Personnel as Percent of Total Expenditures (01-02)

Growth of Tenured/Tenure Track Faculty Dollars (95-96 to 01-02)

Growth of Temporary Faculty Dollars) (95-96 to 01-02)

\begin{tabular}{|l|c|c|c|c|c|c|c|c|}
\hline & AGR & ARTS & BUS & ENG & ENV & SHM & CEIS & SCI \\
\hline $\begin{array}{l}\text { Staff/Admin } \\
\text { \% of T.E. }\end{array}$ & 20.55 & 9.08 & 8.04 & 11.02 & 15.82 & 21.85 & 13.56 & 11.27 \\
\hline $\begin{array}{l}\text { Personnel \% } \\
\text { of T.E. }\end{array}$ & 85.22 & 94.07 & 95.03 & 96.39 & 90.13 & 86.72 & 75.64 & 78.57 \\
\hline $\begin{array}{l}\text { Annual \% } \\
\text { Inc. T\&TT }\end{array}$ & 4.28 & 3.12 & 4.01 & 1.60 & 2.14 & 3.05 & 9.03 & 2.43 \\
\hline $\begin{array}{l}\text { Annual \% } \\
\text { Inc. Temp }\end{array}$ & 16.02 & 10.30 & 7.81 & 8.90 & 13.14 & 2.64 & 10.59 & 17.93 \\
\hline
\end{tabular}

Staff and administration expenditures as a percent of total expenditures are high for the Colleges of Agriculture, Environmental Design and the School of Hospitality Management. These are low FTE units. The School of Hospitality Management began as a department in the College of Business and is smaller in size than all but one of the Business College departments. The College of Agriculture has fewer majors than three of the departments in the College of Business. Yet, both have Deans, Associate Deans and department chairs. Agriculture's administrative structure constitutes a significant component of the high per FTE cost of instruction.

The Colleges' personnel costs as a percent of total expenditures ranges from 75.64 to 96.39 . For the University, these employee costs are 76.75 percent[7]. The Governor has imposed mid-year budget reductions on CSU. The Chancellor, until very recently had asked the President to develop a plan that would absorb cuts but maintain FTE taught. For the large colleges, Business, Arts and Engineering with personnel costs at $95 \%$ of expenditures such plans do not appear feasible.

The dollars spent on tenured and tenure track faculty have failed to keep up with salary increases over the period. Tenured faculty who have retired have not been replaced with tenure track faculty. The Chancellor has given the campuses FTE target figures that are obtainable only through hiring temporary faculty. Ex-governor Davis threw out the Wilson Compact. He and the Chancellor fashioned a "partnership agreement" that provided the governor flexibility in funding requirements but still required access. The 03-04 Budget Act reduced the dollars available for existing operations. While the dollar appropriation was not reduced mandated cost increases were not funded. Additional funds in the form of "growth dollars' were to provided but only for added FTE up to a projected $4 \%$ increase.

\section{CONCLUSION}

The CSU and the University have entered another period of budgetary reductions. The last budgetary cycle witnessed a dramatic decline in FTE. While the enrollments have reached the highs of the early 90's, the focus on Access has been detrimental to Quality. Affordability was given a higher priority than Quality when the already low student fees were reduced and general fund money was used to replace those funds.

The State's budgetary problems have impacted the CSU. The University is experiencing Title Wave II the forecasted large increases in CSU eligible high school graduates. The faculty demographics foretell a significant increase in the number of retirements particularly if workload were to increase significantly. The legislature incorporated budget language in the 03-04 appropriation that provides for zero growth in the CSU 04-05 enrollment. The Chancellor put a freeze on admissions for next year in the fall and announced recently that the mid-year reductions will necessitate a cut in enrollment of one percent. Governor Davis included a $40 \%$ fee increase in the 03 04 budget that followed a mid-year increase of 10 percent. While these fee increases have impacted Affordability the yearly cost to a student of $\$ 2550$ is significantly lower than the cost of other states' public 4 year institutions. The continuing budget crisis will ensure that Access and Affordability join Quality as casualties of State policy. 


\section{REFERENCES}

1. California State Polytechnic University Pomona, University Expenditure Report, 1995-1996.

2. California State Polytechnic University Pomona, University Expenditure Report, 1996-1997.

3. California State Polytechnic University Pomona, University Expenditure Report, 1997-1998.

4. California State Polytechnic University Pomona, University Expenditure Report, 1998-1999.

5. California State Polytechnic University Pomona, University Expenditure Report, 1999-2000.

6. California State Polytechnic University Pomona, University Expenditure Report, 2000-2001.

7. California State Polytechnic University Pomona, University Expenditure Report, 2001-2002.

8. California State University, Statistical Abstract, VII Resources, 1995-1996

9. California State University, Statistical Abstract, VII Resources, 2000-2001

10. www.csupomona.edu/ irap/stats/5yearprofiles.htm

\section{NOTES}




\section{NOTES}

